\title{
Analysis on the Disaster Caused by Qiongshan Earthquake in 1605
}

\author{
HU Jiu-chang, ZHANG Hui, XIE Xiao-ling, WANG hui-lin \\ Hainan Earthquake Agency \\ Haikou, 570203 \\ 2024894446@qq.com \\ 1605 年琼山大地震致灾成因分析 \\ 胡久常 张 慧 谢小玲 王惠琳 \\ 海南省地震局 \\ 海口，570203 \\ 2024894446@qq.com
}

\begin{abstract}
The 7.5 magnitude great earthquake occurred in Qiongshan of Hainan Province ,on July 13, 1605. it didn't only destroy a large number of houses, but also caused a large area of land subsidence in the Dongzhaigang area where the epicenter was located, however, it didn't completely sink to the bottom of the sea. The whole area in Dongzhai Harbor is gradually formed after the Qiongshan great earthquake because of the long-term land subsidence. The earthquake relics in the Harbor, especially the seabed village, were undoubtedly destroyed by the earthquake, but the submergence in the bottom of the sea should be caused by the long-term land subsidence after the great earthquake. When the Qiongshan great earthquake occurred, a large amount of seawater poured into the coastal area of Qiongzhou Strait in the north of Hainan Island, because the earthquake caused seabed collapse and landslide in the Qiongzhou Strait triggering a small tsunami.
\end{abstract}

Keywords-Qiongshan Great Earthquake, Land subsidence, Tsunami

摘要一 1605 年 7 月 13 日海南琼山发生 7.5 级大地震, 不 仅使大量房屋毁于一旦, 还造成震中所在的东寨港地区出现 大面积陆地陷落, 但在当时并未完全沉没于海底。东寨港整 体是在琼山大地震后因陆地长期沉降逐步形成的, 港湾内的 地震遗迹, 尤其是 “海底村庄” 地震遗址, 就其受破坏而言, 无疑是大地震所造成, 但其沉没于海底, 则应是大地震之后 的长期陆地沉降所致。在琼山大地震发生时有大量海水涌入 海南岛北部琼州海峡沿岸地区, 是因为大地震造成了琼州海 峡内的海底崩塌和滑坡，引发了小规模的海啸。

关键词一琼海大地震, 地面沉降, 海啸

$$
\text { I. 引言 }
$$

1605 年 7 月 13 日晚 10 时前后, 在琼州府东北部海 边, 即现在的海南省海口市琼山区东寨港一带, 发生了 7.5 级大地震, 被称为琼山大地震, 或称琼州大地震。这 次大地震及随后不到一年时间内所发生的十多次 6 级以 上强余震，不仅使民舍屋宇夷为瓦砾，也使官署、殿堂、 祠宇等古代豪华建筑物蹦倒殆尽，还造成震中所在的东 寨港地区出现大面积陆地陷落和数十个村庄淹没于海, 据统计, 地震死亡人数达 3300 余人，是我国华南地区历
史上致灾最严重的一次地震。就这次大地震的震害特征 和成因，陈恩民（1979，1989）、彭承光（1983）和徐 起浩 (1985，2007）等人有过不同角度和程度的研究, 前者分析了陆陷沉海的震害特征和成因, 后者则进一步 分析了地震可能引发的海啸及其成因。

2018 年 9 月 28 日，在印尼苏拉威西省中部发生了 7.4 级地震。这次地震的震中位于陆地上, 按理说不会引发 海啸, 但海啸确实发生了, 致使不少人被海啸卷走或被 掩埋在建筑物的废墟下。这次地震和海啸造成 2400 余人 遇难、一万多人受伤、超过 8 万人无家可归。有专家认 为, 由于地震发生在狭长的半岛, 强烈地震使陡峭的海 底产生崩塌和滑坡引发了海啸。

受印尼苏拉威西省 7.4 级地震引发海啸成因的启发, 结合近年来我们对 1605 年琼山大地震的进一步研究, 本 文拟对琼山大地震的致灾成因提出一些新的认识和依据。

\section{II. 大地震造成陆地陷落沉海}

上个世纪七、八十年代, 陈恩民等人通过调查、考 证有关地方志史资料和实地勘察, 找到了因 1605 年琼山 大地震而陷没于海的古村庄、牧场和晒盐场等遗址残迹。 据估计, 地震使 100 余平方千米土地、数十个村庄沉于 海底。彭承光等人通过地震史料考证、野外地质调查、 钻孔土层力学性质分析和场地震害考察等资料的研究, 认为琼山大地震在滨海地带第四纪软土层中诱发了砂土 液化、软土流滑, 造成地基失效和场地不均匀沉陷, 沉 陷幅值为 $1 \sim 3$ 米, 见图 1 。

徐起浩等人根据 $\mathrm{C} 14$ 年龄测定和民间传说调查, 认 为琼山大地震震中区东寨港的大片地区都是琼山大地震 后才缓慢沉没于海的, 见图 2 。东寨港位于海南岛东北 部, 是一个深入陆地达 15 千米的港湾, 一般宽约 4 千米, 最宽达 7 8 千米, 呈喇叭形沿北 $20^{\circ}$ 西延伸。两岸主要 为早更新世玄武岩和全新世海相沉积层。港湾内大部分 为淤泥质浅滩和红树林沼泽区, 并有很多呈岛屿状的大 小高地, 退潮后淤泥质浅滩和红树林沼泽区散布有大量 


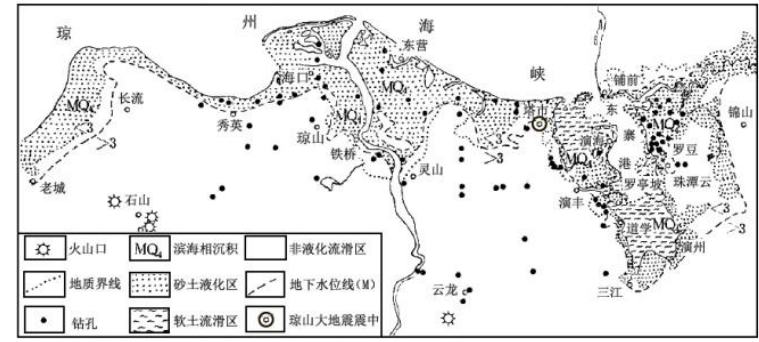

图 1 琼山大地震地基砂土液化和软土流滑地区分布图 (据彭承光，1983）

的坟墓和其它废墟。古村庄地震遗址分布在东寨港港湾 地带的北港岛、北洋港、道学村、罗亭坡等处。据史料 记载和现今调查, 推测东寨港地区近代大约以每年 0.5 厘米的速度下沉, 自 1605 年琼山大地震后至今, 下降幅 度已达 2 米左右。张振克等（2010）根据东寨港红树林 区岩芯地球化学特征及其古地震指示分析, 1605 年琼山 大地震至今东寨港区域沉陷的幅度至少有 $1.6 \sim 1.8$ 米。 根据 2009 年 8 月对东寨港进行的水下勘察，整个东寨港 的水下地形平坦, 绝大部分水域的水深小于 1 米, 其内 一条纵观南北的潮沟底部水深在 3 5 米之间。另据记载, 在清道光年间（1821-1850）文昌县地图上东寨港是用 河流表示的。这说明东寨港大部分地区在 1605 年琼山大 地震后仍为陆地。

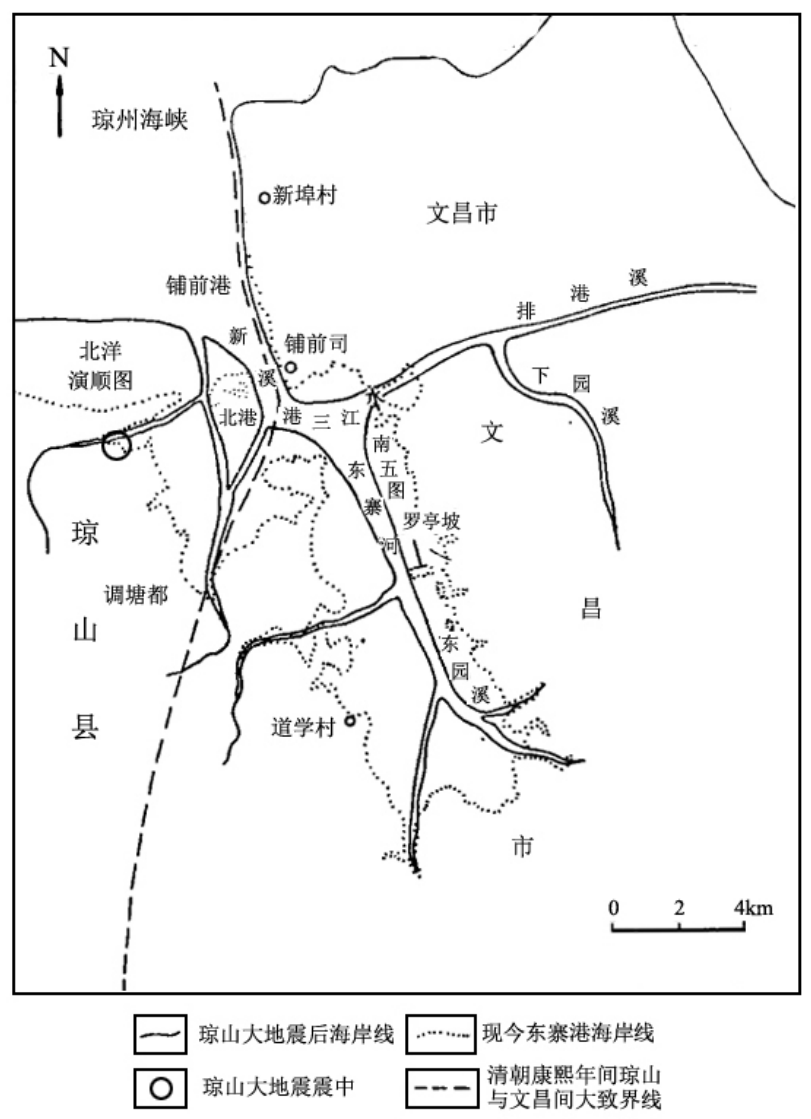

图 2 琼山大地震后东寨港及邻区海岸线演化图（据 徐起浩，1986）
由此推测, 东寨港整体是在 1605 年琼山大地震后逐 步形成的, 地震造成东寨港地区出现大面积陆地陷落, 但在当时并未沉没于海底。东寨港港湾内的地震遗迹, 尤其是 “海底村庄” 地震遗址, 就其遭受的破坏而言, 无疑是 1605 年琼山大地震所造成, 但其沉没于海底, 则 应是大地震之后的长期陆地沉降所致。

\section{III. 大地震诱发海底崩塌滑坡引发海啸}

据史志、家（族）谱记载, 1605 年 7 月 13 日琼山大 地震时, 有大量村庄平地陷落成海和桑 (盐) 田变海, 以及灾民溺水而亡。这无疑说明在大地震发生时有大量 海水涌入海南岛北部琼州海峡沿岸地区。徐起浩（2007） 认为这次大地震造成的海岸同震急剧下沉可能引发了海 啸。

受印尼苏拉威西省 7.4 级地震使沿海岸海底陡坡产生 崩塌和滑坡引发了海啸的启发, 我们推测琼山大地震可 能在琼州海峡内产生崩塌和滑坡, 从而引发了海啸。为 证实这一推测, 我们查找了大量资料和文献, 找到了琼 州海峡确实存在海底陡坡和产生崩塌、滑坡后的堆积物, 以及存在海啸沉积层的证据。

琼州海峡是雷琼断陷内雷南火山与琼北火山之间的 低地。海峡东西长约 80 千米, 南北宽约 30 千米, 最窄 在东部, 宽约 18.6 千米。海峡东深西浅, 中部是水深大 于 50 米、宽 10 约千米、长约 70 千米的深水盆地, 其中 轴为水深 $80 \sim 114$ 米的深水槽。在海峡中部还有水深小 于 50 米的区域, 东西长约 10 千米, 为未被冲蚀的中垣 (孤丘)。海峡南北两侧多为陡坡, 最大高差达 70 米, 坡度最大可达 $22^{\circ} \sim 24^{\circ}$, 见图 3。陡坡地地层为可塑 一硬塑的黏性土和砂夹黏土, 局部为块状玄武岩。詹文 欢 (1989) 、蒋俊杰（2010）等人认为, 琼州海峡内陡 坡是滑坡容易产生的地段, 强震、强潮流或风暴引起的 风浪往往能诱发灾害性的崩塌和滑坡。彭学超（1999） 根据琼州海峡物探资料反演单道地震剖面显示海峡内陡 坡底部存在滑坡, 滑塌面十分清楚, 滑坡堆积内部发射 层已被弯曲变形。蒋俊杰等人 (2010) 利用旁扫声纳显 示琼州海峡南部隆起带北坡坡脚有块状物堆积体。叶春 池等人 (1986) 通过分析琼州海峡沉积类型和沉积特征, 发现海峡冲刷槽普遍堆积了较粗的砾石, 通过现场取样 分析得知, 砾石主要由石英、玄武混合岩等碎屑物组成, 多呈棱角装或次棱角状, 磨圆度极差, 频率曲线由推移 总体和悬移总体组成。在平面型态和砂粒沉积物呈舌状 由东西口向海峡中部伸展, 于海口湾外冲刷深槽互相靠 拢，然后共同折向北岸。

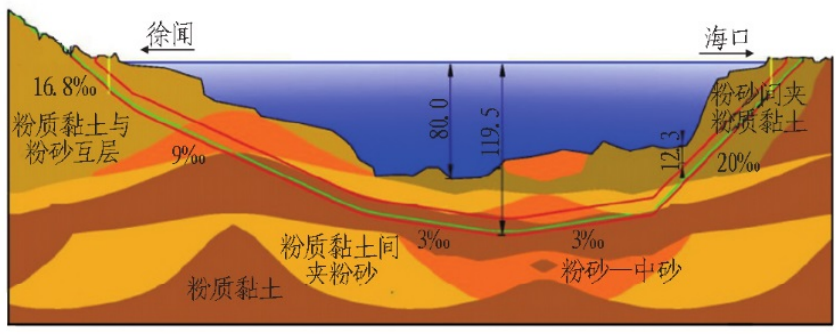

图 3 琼州海峡地质剖面示意图（据谭忠盛，2018）

根据以上资料和文献, 我们推测 1605 年的琼山大地 震造成了琼州海峡内的海底崩塌和滑坡。至于琼州海峡 
内的海底崩塌和滑坡能否引发海啸, 我们查阅了孙永福 等人（2018）撰写的《海底滑坡海啸的颗粒流耦合模 型》, 根据其以南海北部海底物质（与琼州海峡内海底 物质基本相同）所做的模拟海底滑坡实验，证实水下滑 体与水体的交互作用使得水面产生涌浪，形成了海啸。

海啸沉积层遗迹被认为是沿海地带是否发生过海啸 的重要标志。至今在琼州海峡沿岸尚未找到海啸沉积层 遗迹，这并不能否定 1605 年琼山大地震引发过海啸，可 能说明这次大地震引发的海啸规模较小，依据自 1605 年 琼山大地震后震中所在的东寨港地区的下降幅度已达 2 米左右, 而现今东寨港绝大部分水域的水深小于 1 米, 推测琼山大地震造成琼州海峡海底崩塌和滑坡引发的海 啸涌浪高度为 $1 \sim 2$ 米。如此, 由这次海啸产生的沉积层 遗迹因大地震后的陆地长期下沉而淹没于现今海平面以 下。张振克等人 (2010) 通过对东寨港红树林区岩芯的 粒度和元素地球化学分析, 发现地球化学元素含量在 $125 \mathrm{~cm}$ 附近有明显突变, 对应沉积物从陆相向海相转变。 该沉积相突变不仅是对 1605 年琼山大地震事件的响应, 也是东寨港地区存在海啸沉积层的证据。

\section{IV. 结语}

长期以来，对 1605 年琼山大地震造成陆地陷落沉海 的原因一直存在争议。我们通过不断积累资料、查阅各 种文献以及实地考察和综合分析, 认为这些争议相互之 间并无根本性矛盾，主要是依据资料的完整性和分析的 角度不同所致。东寨港整体是在 1605 年琼山大地震后逐 步形成的, 地震造成东寨港地区出现大面积陆地陷落,
但在当时并未沉没于海底。东寨港港湾内的地震遗迹, 尤其是 “海底村庄” 地震遗址, 就其遭受的破坏而言, 无疑是 1605 年琼山大地震所造成, 但其沉没于海底, 则 应是大地震之后的长期陆地沉降所致。在琼山大地震发 生时有大量海水涌入海南岛北部琼州海峡沿岸地区, 是 因为大地震造成了琼州海峡内的海底崩塌和滑坡, 引发 了小规模的海啸。

\section{参考文献}

[1] 陈恩民, 黄詠茵. 1605 年海南琼州大地震的震害特征和发震构造 研究.地震学报.11 (3) : 319 331,1989.

[2] 蒋俊杰, 张志强, 魏志强. 琼州海峡海底电缆路由工程地质特征. 海洋测绘，30 (2) : 58 60, 2010 .

[3] 彭承光. 1605 年 7 月 13 日琼州历史地震陆沉原因. 地震地质, 5 (3) : 9 15, 1983

[4] 彭学超. 琼州海峡物探资料解释及灾害因素分析. 热带海洋, 18 (2) : 72 778, 1999 .

[5] 孙永福, 黄波林, 宋玉鹏, 赵永波.海底滑坡海啸的颗粒流耦合 模型.岩土力学，39（9）：3469～3476, 2018.

[6] 谭忠盛, 贺维国, 王梦怒. 琼州海峡工程地质条件及铁路隧道方 案研究.隧道建设（中英文），38（1）：1～7,2018.

[7] 徐起浩.海南岛北部东寨港的形成、变迁与 1605 年琼州大地震. 地 震地质，8（3）：92９6, 1986.

[8] 徐起浩. 1605 年琼州大地震陷落沉海和可能的海啸.海洋学报, 29 (3) : 146 156, 2007.

[9] 叶春池.琼州海峡沉积与地形发育. 热带地理, 6 (4) : 346 353, 1986

[10] 詹文欢, 刘以宣.琼州海峡的断裂构造与区域稳定性分析.热带海 洋, 8（4）： 70 77, 1989.

[11] 张振克, 孟红明, 谢丽, 等.海南岛东寨港红树林区岩芯地球化 学特征及其古地震指示. 地理科学, 30（5）：777〜 782，2010。 